\section{SIMULATION ANALYSIS ON $\mathrm{SO}_{2}$ REDUCTION INSIDE A SEAWATER SCRUBBER}

\author{
Nur Tantiyani Ali Othman*, Norzatul Ashirah Mohd Alias
}

Research Centre for Sustainable Process Technology, Programme of Chemical Engineering, Faculty of Engineering and Built Environment, Universiti Kebangsaan Malaysia, 43600, Bangi UKM, Selangor, Malaysia
Article history

Received

29 March 2019

Received in revised form

7 August 2019

Accepted

20 August 2019

Published online

24 October 2019

*Corresponding author tantiyani@ukm.edu.my

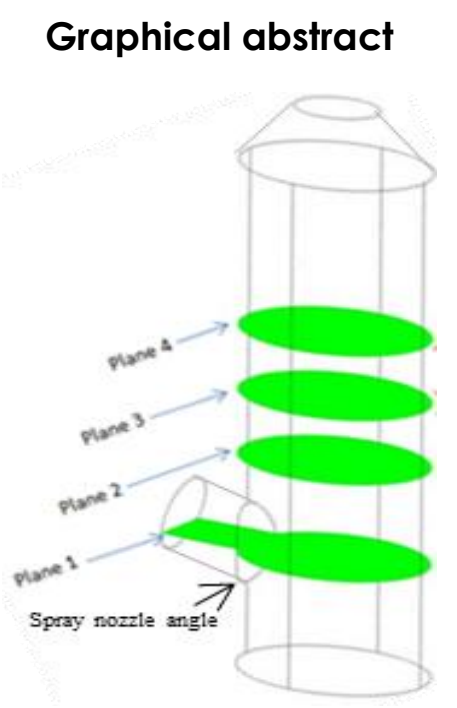

\begin{abstract}
The marine industry is one of the industrial sectors that release sulphur dioxide $\left(\mathrm{SO}_{2}\right)$ into the atmosphere as a result of heavy fuel oil's combustion as an energy source. Generally, flue gas desulphurization method has been used to control the $\mathrm{SO}_{2}$ emission where seawater used as the alkaline slurry. However, usually the gas velocity at the scrubber's wall is moderately high that could contribute to the uneven distribution of liquid droplets over the entire domain surface, and consequently can affect the amount of $\mathrm{SO}_{2}$ reduction released. Hence, the purpose of this study is to observe the gas flow pattern in the scrubber and to determine the effect of a spray nozzle angle on the $\mathrm{SO}_{2}$ reduction released. The scrubber with $4.46 \mathrm{~m}$ in the height, $1.35 \mathrm{~m}$ in the diameter and spray nozzle angle between $80-120^{\circ}$ was designed using Ansys Fluento version 17.2. Three factors which are gas velocity, pressure, and temperature of gas were studied to achieve the optimum $\mathrm{SO}_{2}$ reduction. The simulation result shows the declination trend in these three factors on the gas distribution as the angle of the spray nozzle is increased. The percentage of $\mathrm{SO}_{2}$ reduction is increased up to $17 \%$ for the spray nozzle angle between $80-120^{\circ}$.
\end{abstract}

Keywords: Scrubber, spray dryer, nozzle angle, Ansys Fluent ${ }^{\odot}, \mathrm{SO}_{2}$ reduction

\begin{abstract}
Abstrak
Industri marin adalah salah satu sektor perindustrian yang melepaskan gas sulfur dioksida $\left(\mathrm{SO}_{2}\right)$ ke atmosfera akibat dari pembakaran minyak bahan bakar berat sebagai sumber tenaga. Secara amnya, kaedah desulfurisasi gas serombong telah digunakan untuk mengawal pelepasan $\mathrm{SO}_{2}$ di mana air laut digunakan sebagai buburan alkali. Walau bagaimanapun, biasanya halaju gas di permukaan penggahar adalah tinggi yang boleh menyumbang kepada pengagihan titisan cecair yang tidak sekata sekal gus menjejaskan jumlah pengurangan gas $\mathrm{SO}_{2}$ yang dikeluarkan. Oleh itu, tujuan kajian ini adalah untuk melihat corak aliran gas dalam penggahar dan untuk menentukan kesan sudut muncung semburan ke atas pengurangan gas $\mathrm{SO}_{2}$ yang dibebaskan. Penggahar dengan ketinggian 4.46 $\mathrm{m}$, diameter $1.35 \mathrm{~m}$ dan sudut muncung semburan antara $80-120^{\circ}$ direka menggunakan perisisan Ansys Fluentఠ versi 17.2. Tiga faktor iaitu halaju gas, tekanan, dan suhu gas dikaji untuk mencapai pengurangan gas $\mathrm{SO}_{2}$ yang optimum. Hasil simulasi menunjukkan trend penurunan pengagihan gas dalam tiga faktor ini apabila sudut muncung semburan meningkat. Didapati, peratusan pengurangan gas $\mathrm{SO}_{2}$ meningkat sehingga $17 \%$ untuk sudut muncung semburan antara $80-120^{\circ}$.

Kata kunci: Penggahar, pengering semburan, sudut muncung, Ansys Fluent ${ }^{\odot}$ pengurangan gas $\mathrm{SO}_{2}$
\end{abstract}

(C) 2019 Penerbit UTM Press. All rights reserved 


\subsection{INTRODUCTION}

Marine heavy fuel oil contains about 2,000 times as much sulphur as standard automobile diesel and once it spills to the ocean, it can harm the marine life and extremely hard to clean. The latest statistic shows over 760 million cars that are currently operating worldwide which has been contributed to the sulphur emit as much as almost 15 container ships that running at full capacity and on top of that there are currently 6000 massive container ship and about 85,000 commercial cargo ship operating globally [1-5].

Generally, the combustion of the fuel as a source of energy produces sulphur dioxide $\left(\mathrm{SO}_{2}\right)$ which is harmful both to the environment and human health. The excess of the $\mathrm{SO}_{2}$ in the atmosphere environment can be harmful to human by affecting the respiratory tract when present at the high concentration. For the environment, it can cause acid rain since $\mathrm{SO}_{2}$ can oxidize to sulphur trioxide $\left(\mathrm{SO}_{3}\right)$ to form $\mathrm{H}_{2} \mathrm{SO}_{3}$ (sulphuric acid) when in contact with the water that can cause deterioration of natural water systems, crop yield reduction and damaging buildings among others [68]. Due to the large emission of $\mathrm{SO}_{2}$ gas, a series of restriction have been implemented since early of 1970 until now. Alternative measures such as exhaust gas scrubbers, combine with the use of heavy fuel oil are allowed to reduce the sulphur emission.

Every year, the issue on the environmental impacts is increasing especially the release of flue gas by the marine and automotive engines, which particularly to release of $\mathrm{SO}_{x}$ gases and particulate mass. Because of that, the $\mathrm{SO}_{2}$ emissions are strictly controlled by an international and national regulations by establishing a maximum emission limit of $\mathrm{SO}_{2}$ to the atmosphere [9]. The main purpose of this regulation is to improve the ambient of the air quality and to prevent an excessive release of $\mathrm{SO}_{2}$ into the environment. The regulations on the controlling of the sulfur content in flue gas at the global level are expected to take an effect from 2020 or 2025. Thus, one of the alternative ways for ship owners to comply with these rules is to convert fuel from high to the low sulfur content but with a good quality. However, the low sulfur content with a good quality is more expensive than a heavy fuel where the price has doubled since in January 2016 [10]. This significant increasing of the fuel price has made the shipping companies turn to the usage of a heavy fuel oil with seawater scrub in order to remove the $\mathrm{SO}_{2}$ from their flue gas.

The study by Everson. R. C. et al. [11] shows the flue gas velocity is high near to the scrub's wall where it is located opposite to the flue gas inlet. They observed that the water spray drops are not evenly distributed across the plane surface in the scrubber. Besides, they found the flue gas velocity could be controlled by changing the nozzle spray angle at each spray's stage. By changing the spray angle, it indirectly reduces the cost of a system execution as well can reduce the risk of an inadequate pollution reductions.
Although the analysis through laboratory experiments can provide a better assessment of the characteristics of the sprayer in the scrubber, but it often involves a high cost or physically impossible. In addition, the operating engineers usually rely on the expertise experience and past case studies to solve problems. To overwhelmed of this constraint, the computer aided; computational fluid dynamic (CFD) technique has been chosen as the best option to observe and predict what is happening in the scrubber as well as to validate the system performance through experiments and reducing the risks involved. With the CFD technique, the engineers are able to assess the quality of the sprayers in the actual spraying area, thus reducing the rate of $\mathrm{SO}_{2}$ emissions to the environment [12].

Besides, to control $\mathrm{SO}_{2}$ emission to the atmosphere, generally, Flue Gas Desulphurization (FGD) method has been applied where seawater was used as the alkaline slurry due to its low operating cost. The FGD method is typically performed in wet scrubbers, where the absorption mean is a water slurry containing fine particles of limestone (or other alkaline absorbent species). In this way, Sox absorption rate is enhanced by reaction with dis-solved particles, which provide a continuous alkaline reagent supply. But, it has been suggested that in areas close to the sea seawater scrubbing is an economically attractive solution rather than a slurry, where scrubbing performance relies on seawater natural alkalinity [2]. The advantages of using a seawater involve simple plant design, no addition of chemicals and no solid by-products. The acidified effluent can be discharged directly into the sea, after a further neutralization step obtained by mixing with fresh sea-water and additional forced oxidation of sulfite ions by air blowing.

However, for the marine application, seawater is more promising from the availability aspect, in fact, the acidified effluent can be discharged directly into the sea after a simple neutralization process [13]. In addition, usually the gas velocity is moderately high at the scrubber's wall which affecting to uneven distribution of liquid droplets over the entire domain surface and consequently can affect the amount of $\mathrm{SO}_{2}$ reduction released in the scrubber. Therefore, an effective method or procedure is required in order to reduce the wet FGD cost as well to control the effluent pollution.

In this study, the effect of the spray nozzle angle on the $\mathrm{SO}_{2}$ reduction was determined. The scrubber with $4.46 \mathrm{~m}$ in height, $1.35 \mathrm{~m}$ in diameter and spray nozzle angle between $80-120^{\circ}$ was designed by using Ansys Fluent ${ }^{\circ}$ academic version 17.2 [14]. This range value of the nozzle angle was chosen as refer to 'A User's Guide to Spray Nozzle' [15] where to determine the theoretical coverage for the scrubber diameter more than $90 \mathrm{~cm}$, the optimum nozzle angle is between 85 $110^{\circ}$. Besides, three factors; gas velocity, pressure, and temperature of gas were studied in order to determine the optimum $\mathrm{SO}_{2}$ reduction. 


\subsection{METHODOLOGY}

There are five steps in the computational fluid dynamic (CFD) process in order to observe and determine the $\mathrm{SO}_{2}$ reduction in the seawater scrubber. The details CFD processes including of geometry, meshing, set boundary condition, set initial parameter and solve for a result is shown in Figure 1. First, by using a Design Modeller ${ }^{\odot}$ software, the 3D model of the seawater scrubber is designed by selecting of an appropriate coordinate. In this study, the selected domain size and geometry shape is based on the typical scrubber model that was used in the most marine industry. The scrubber was designed based on the standard of sizing set by Wartsila Scrubber Product Guide [16].

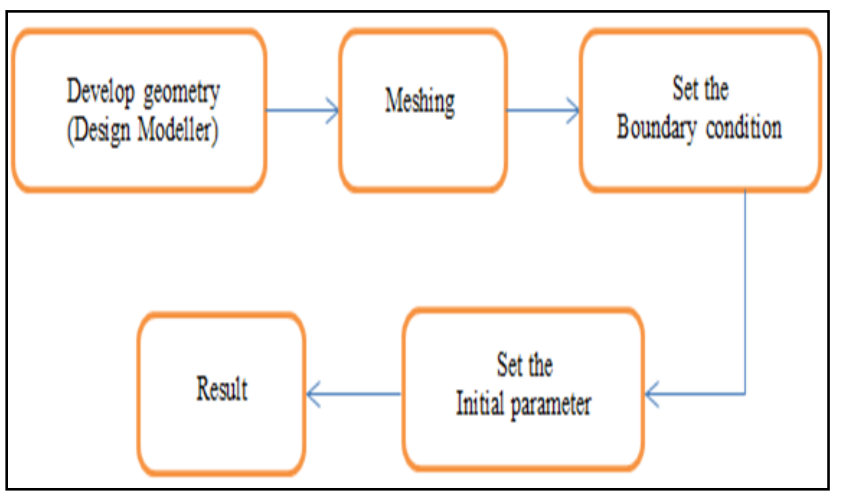

Figure 1 Sky Five steps in the CFD process

\subsection{Develop Geometry and Meshing}

Figure 2 (a) and (b) shows the schematic and 2D diagram of the scrubber, respectively which was designed by using a Design Modeller ${ }^{\odot}$ software. Its dimension is $4.46 \mathrm{~m}$ in the height and $1.35 \mathrm{~m}$ in the diameter. The diameter of both air's inlet and outlet are $0.6 \mathrm{~m}$ and the inlet of air section has $15^{\circ}$ cut off to provide better interaction between the gas-liquid phases in the scrubber. There are four planes are attached inside the seawater scrubber that was used as the water inlet supply. To observe the gas flow pattern inside the scrubber, the plane section is designed at the appropriate four different locations with the distance between each plane is $0.5 \mathrm{~m}$. Plane 1 is located $0.8 \mathrm{~m}$ from the bottom side of a scrubber, plane 2 is located $0.77 \mathrm{~m}$ from the plane 1 while for the plane 3 and 4 are located at $0.5 \mathrm{~m}$ from the previous plane respectively.

Figure 2 (c) shows the mesh generated from ANSYS Mesh. For the meshing process, the seawater scrubber model has meshed into 419802 polyhedron cells and nodes of 76 925. As compared to the other type of cells, the polyhedron had several advantages; that can produce a more accurate result, rapid convergence with fewer iterations and provides a faster settlement period. Local meshing is done at three locations which is the inlet, outlet and the body plane of scrubber. This is to refined the meshing properties at these 3 locations. Global mesh is then generated. A mesh independence study is then carried out to determine that the mesh generated is accurate for CFD simulation.

\subsection{Set the Boundary Condition and Initial Parameter}

The details setting of a boundary condition for inlet and outlet gas is shown as in Table 1. These data were obtained based on the common standards material properties that were applied in the mostly marine industry and previous researchers [17]. The hot air fed to the scrubber with the mass flow rate of $3.056 \mathrm{~kg} / \mathrm{s}$ at temperature $500 \mathrm{~K}$ and $25 \%$ of $\mathrm{SO}_{2}$ mass fraction. The gas then was released through the atmosphere at $101.324 \mathrm{kPa}$.

Table 1 The parameter of materials in the scrubber [12]

\begin{tabular}{llcc}
\hline $\begin{array}{l}\text { Boundary } \\
\text { condition }\end{array}$ & \multicolumn{1}{c}{ Parameter } & Value & Unit \\
\hline \multirow{4}{*}{ Inlet gas } & Mass flow rate & 3.056 & $\mathrm{~kg} / \mathrm{s}$ \\
& Temperature & 500 & $\mathrm{~K}$ \\
& Mass fraction of $\mathrm{SO}_{2}$ & 0.25 & $\mathrm{~W} / \mathrm{W} \%$ \\
& Gas velocity & 35 & $\mathrm{~m} / \mathrm{s}$ \\
\hline Outlet gas & Pressure & 101.324 & $\mathrm{kPa}$ \\
\hline Wall & Adiabatic & & \\
\hline
\end{tabular}

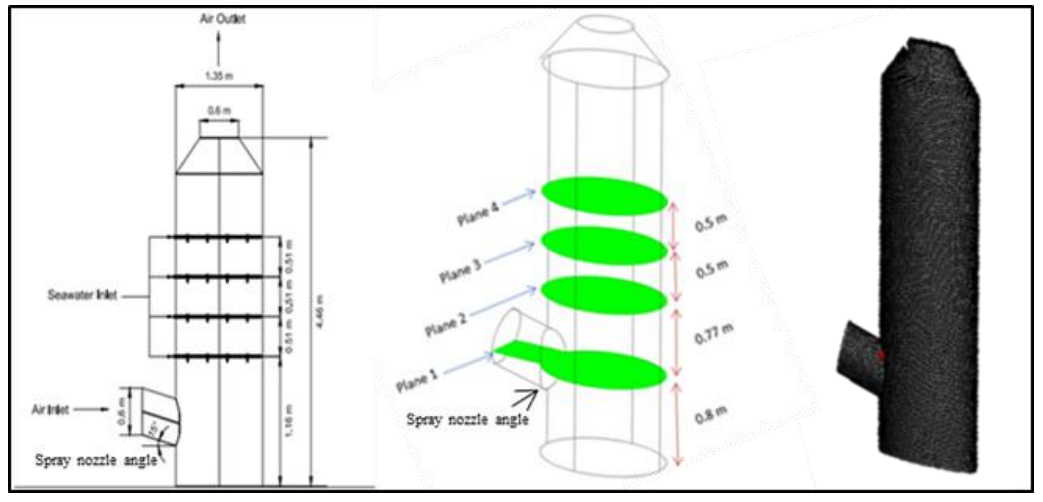

(a) (b) (c)

Figure 2 2D Scrubber model; (a) Schematic diagram, (b) 2D diagram with a position of 4 planes and (c) meshing of seawater scrubber 
The Discrete Phase Model (DPM) was used as the injection method for spray the seawater droplets through the nozzles. The details properties for the liquid injection of the seawater is shown as in Table 2. The droplet diameter of $0.5 \mathrm{~mm}$ is used where this kind of droplet size can prevent the droplets to be carried along the gas flow emitted from the scrubber through the outlet gas section. In this study, the angle of the spray nozzle was adjusted in a range of 80-120 to observe the gas flow profile at four planes based on the gas velocity, pressure and temperature distribution.

Table 2 Properties of seawater droplets injected and sprayed through the nozzle [16]

\begin{tabular}{ccc}
\hline Properties & Value & Unit \\
\hline Temperature & 300 & $\mathrm{~K}$ \\
Type of nozzle & Full cone & - \\
A total mass flow rate & 12 & $\mathrm{~kg} / \mathrm{s}$ \\
Velocity & 60 & $\mathrm{~m} / \mathrm{s}$ \\
Diameter & 0.5 & $\mathrm{~mm}$ \\
Spray nozzle angle & $80-120$ & $\circ$ \\
\hline
\end{tabular}

\subsection{Absorption Phenomena in a Seawater Droplet}

Besides, with manipulated at a different range of spray nozzle angle, the mass fraction of $\mathrm{SO}_{2}$ gas at the gas outlet was determined as well the percentage of $\mathrm{SO}_{2}$ reduction in the scrubber are calculated. Generally, the traditional wet scrubbing applies in the marine industry use an alkaline absorbent slurry for sulphur capture, however, the seawater scrubbing depend on the natural alkalinity. The natural alkalinity is defined as the sum of the concentrations of the alkaline species contained in seawater [17-18]. The value of alkalinity is not fixed, however changes according to the topographical area.

In the case of a seawater spray dryer, an ensemble of falling down droplets encounters counter-currently the exhaust gas flow, which contains sulfur oxides (SO). When a single droplet is exposed to the exhaust gas stream, an $\mathrm{SO}_{2}$ flux forms towards the liquid-gas interface [17]. By refer to the Henry's law [19-20], $\mathrm{SO}_{2}$ can achieve an equilibrium between gas and liquid phases at the droplet surface. In the first stage of the process, while the seawater droplet is still concentrate in alkaline species, suddenly $\mathrm{SO}_{2}$ is consumed at the surface within a thin layer and is unable to penetrate into the droplet. A simplified expression of the chemical processes inside the droplet can be obtained from three reactions expressed in 2.10-2.14:

$$
\begin{gathered}
\mathrm{SO}_{2}(\mathrm{~g}) \rightarrow \mathrm{SO}_{2}(\mathrm{aq}) \\
\mathrm{SO}_{2}(\mathrm{aq})+2 \mathrm{H}_{2} \mathrm{O}(\mathrm{l}) \rightarrow \mathrm{HSO}_{3}^{-}(\mathrm{aq})+\mathrm{H}_{3} \mathrm{O}^{+}(\mathrm{aq})(2.11) \\
\mathrm{H}_{3} \mathrm{O}^{+}(\mathrm{aq})+\mathrm{H}_{2} \mathrm{O}(\mathrm{l}) \rightarrow \mathrm{SO}_{3}^{2-}(\mathrm{aq})+\mathrm{H}_{3} \mathrm{O}^{+}(\mathrm{aq})(2.12) \\
\mathrm{HCO}_{3}^{-}(\mathrm{aq})+\mathrm{H}_{3} \mathrm{O}^{+}(\mathrm{aq}) \rightarrow \mathrm{CO}_{2}(\mathrm{aq})+2 \mathrm{H}_{2} \mathrm{O}(\mathrm{l})(2.13)
\end{gathered}
$$

$$
\mathrm{CO}_{2}(\mathrm{aq}) \rightarrow \mathrm{CO}_{2}(\mathrm{~g})
$$

As that the diffusion coefficient is similar or all the ions species involved, alkaline species can be characterized by a single species $\mathrm{HCO}_{3}$ having a concentration equal to the sum of the all alkaline species. Thus, to model the $\mathrm{SO}_{2}$ alkaline reaction with the global reaction is potential and it is assumed to be very fast [18, 21]. The governing equations for the Eulerian multiphase model include conservation of mass, momentum and energy. The equations of solid and gas phases are developed based on the EulerianEulerian model, using the averaging approach [20].

\subsection{RESULTS AND DISCUSSION}

The effect of using a different angle of the spray nozzle on the gas flow pattern in term of velocity distribution, pressure and temperature have been observed at the four planes as well as to determine the reduction of $\mathrm{SO}_{2}$ inside the scrubber. The reduction of $\mathrm{SO}_{2}$ gas inside the scrubber was determined based on the remaining $\mathrm{SO}_{2}$ mass fraction at the outlet gas section. The angle of the spray nozzle was adjusted in the range of 80 120 to determine which angle could give the best reduction of $\mathrm{SO}_{2}$. The simulation results on the effect of different spray nozzle angle on the gas velocity and gas temperature at the four planes is discussed details in the below section. With these simulation results, the engineers are able to assess the quality of the sprayers in the actual spraying area, thus reducing the rate of $\mathrm{SO}_{2}$ emissions to the environment.

\subsection{Effect of Different Spray Nozzle Angle on the Gas Velocity at Four Planes}

Figure 3 shows the simulation results of the gas velocity distribution at the different angle of the spray nozzle; 80-120 at the four planes; plane 1-4 inside the scrubber. The red color in the velocity contour represents the highest velocity distribution with the value of $35 \mathrm{~m} / \mathrm{s}$ while the blue color represents the lowest velocity distribution with the value of nearly to 0 $\mathrm{m} / \mathrm{s}$. As the overall, the simulation result shows at the plane 1, the maximum velocity obviously indicated at the center area of the scrubber and it slightly decreases up to $35 \%$ at the plane 2 and 3 where the velocity near to the right wall's scrubber is relatively higher compared to the center area of a scrubber. It was happened as the seawater was injected and sprayed through the nozzle, the interaction and collision between the gas-liquid molecules occurred in the scrubber that reduces the movement of the gas velocity. Besides, it is shows that the mixing process occurred between the gas and seawater droplets. Meanwhile, at the plane 4, the minimum velocity distribution was observed with the range of velocity distribution is less than $1 \mathrm{~m} / \mathrm{s}$. 
In term of a different angle of the spray nozzle; $80^{\circ}$ 1200, the simulation result was compared between plane 2, plane 3 and 4 as the plane 1 practically showing the same gas velocity distribution even at different spray nozzle angle due to its position that close to inlet area. From Figure 3, it was show as the opening size of the spray nozzle angle increased, the gas velocity distribution at the scrubber wall is decreased. As the spray nozzle angle of $80^{\circ}$ and $90^{\circ}$ is applied, the turbulent velocity was observed at the center and toward the right corner of the scrubber wall. Meanwhile, as the spray nozzle angle keep increased from $100^{\circ}$ to $120 \circ$, the minima (laminar) velocity shown with the range velocity is between 7.0 to $19 \mathrm{~m} / \mathrm{s}$. It is due to the increment size of the spray nozzle angle, the seawater droplets were distributed through the wider wall area, thus the interaction between the gas and seawater droplets occurred rapidly.

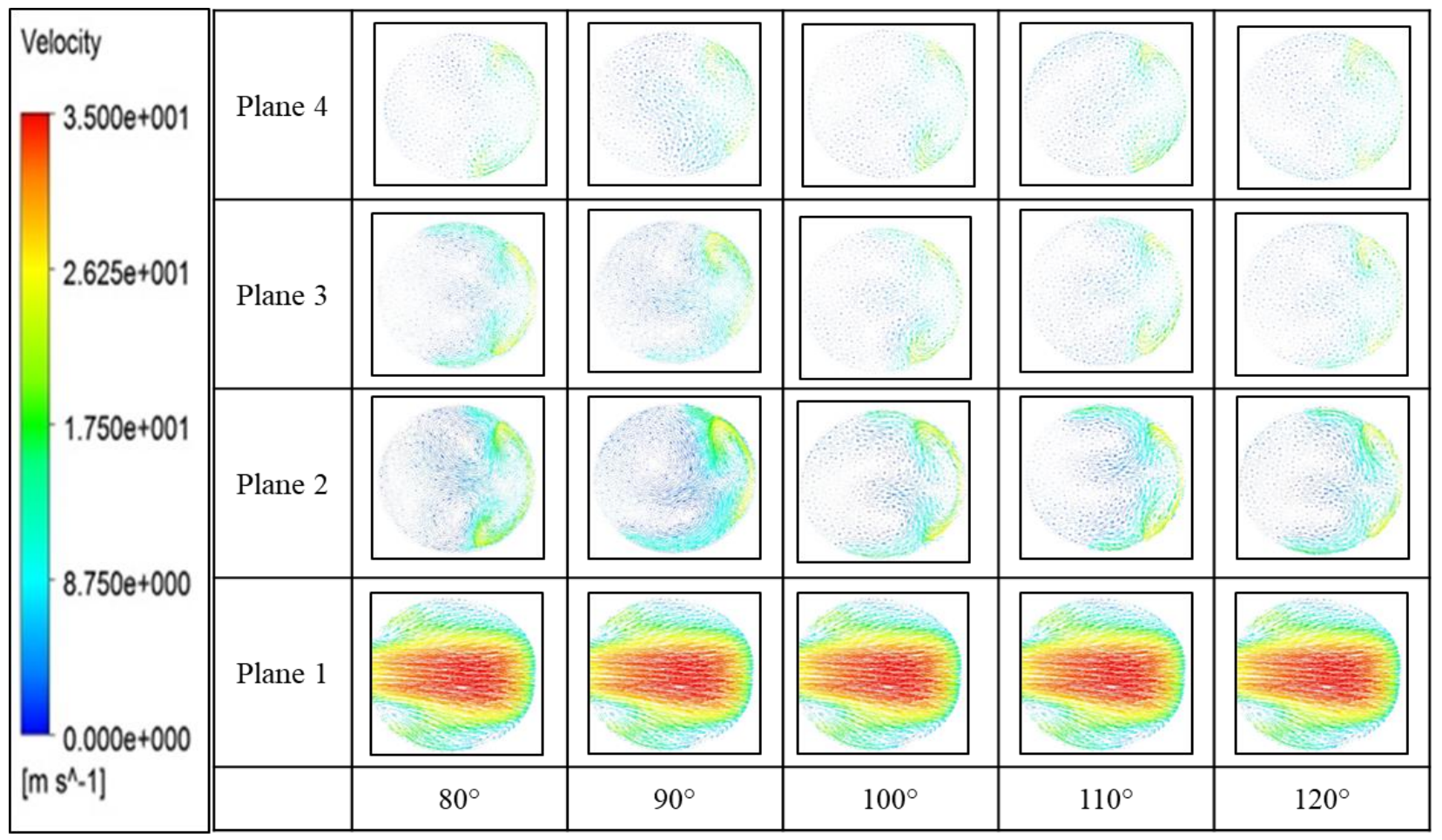

Figure 3 Gas velocity distribution at a different angle of the spray nozzle at four planes inside the scrubber

Besides, as compared to the plane 2, the velocity distribution at plane 3 shown the lower velocity value which is around $8.3 \%$ that much lower than the velocity at plane 2 . The velocity range was observed at $7.8-21 \mathrm{~m} / \mathrm{s}$ when the spray nozzle angle of $80^{\circ}$ is applied and decreased to $7.4-20 \mathrm{~m} / \mathrm{s}$ at $90^{\circ}$. For the rest of the spray nozzle angle; 100。, 1100, and 1200, the velocity distribution range keep declined to 7.2-18.0 $\mathrm{m} / \mathrm{s}$. The spray nozzle angle of 120 at the plane 4 shows the lowest value of the velocity distribution which is $6.8-15.6 \mathrm{~m} / \mathrm{s}$, meanwhile the highest value of velocity distribution which is 7.3-19.6 m/s when the spray nozzle angle of $110^{\circ}$ is applied.

\subsection{Effect of Different Spray Nozzle Angle on the Gas Temperature at Four Planes}

Figure 4 shows the simulation results of the gas temperature distribution at the different angle of the spray nozzle; 80-120 at the four planes; plane 1-4 inside the scrubber. The red color in the temperature contour represents the highest temperature distribution with the value of $500 \mathrm{~K}$ while the blue color represents the lowest temperature distribution with the value of $317 \mathrm{~K}$. Due to high inlet temperature fed to the scrubber at the temperature $500 \mathrm{~K}$ and velocity of 35 $\mathrm{m} / \mathrm{s}$, almost all the area inside the scrubber at the plane 1 results the maximum temperature profile distribution with some temperature declination. However, at plane 2, 3 and 4, the temperature slightly decline with the range of temperature is about 330$460 \mathrm{~K}$. The declination of the temperature occurred due to the collision between the hot air and droplets which lead to the evaporation process that helps to cool down the temperature at the area inside the scrubber.

At the plane 2, the temperature distribution area at the right corner wall is increased as the opening size of the angle of the spray nozzle is increased. At near the scrubber wall, the temperature distribution range is between 400-500 K while at the center and left corner wall, the temperature distribution is below than $350 \mathrm{~K}$. It is due to the feed gas velocity was uneven distributed over the planes that lead to the non-uniform interaction between the gas and seawater droplets. 


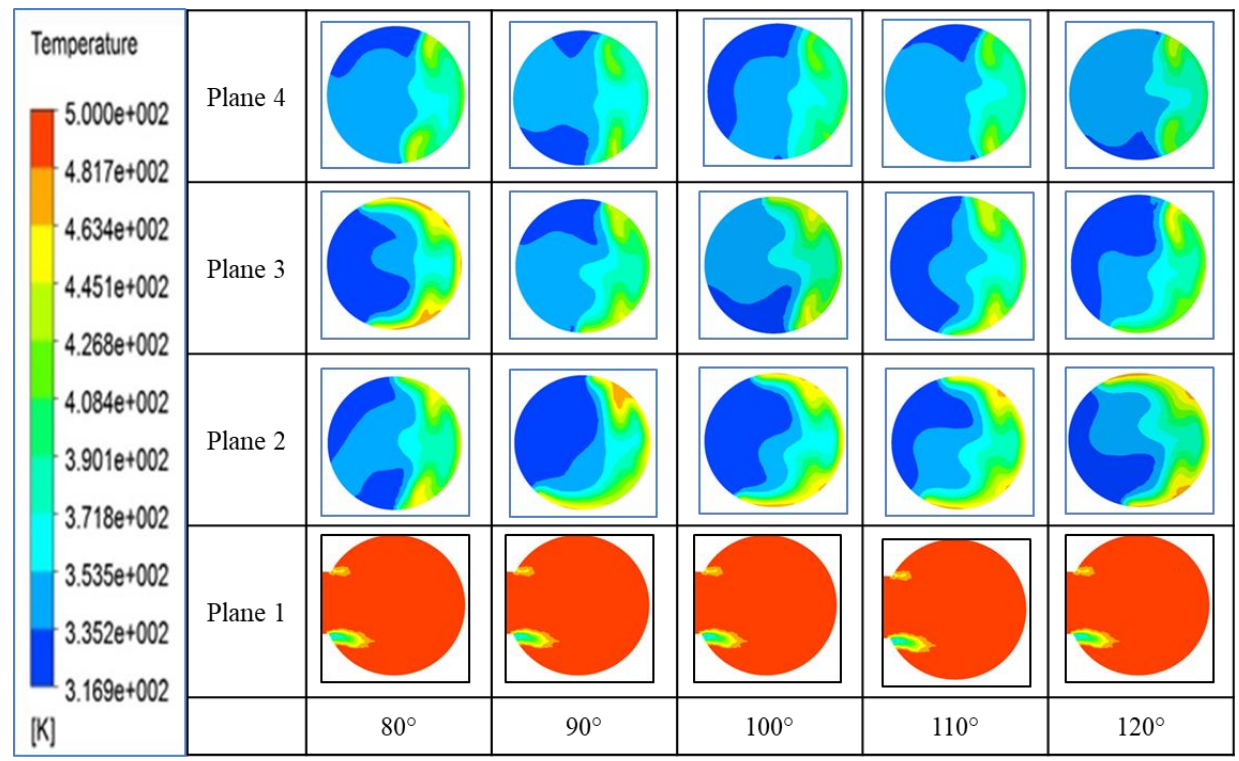

Figure 4 Gas temperature distribution at a different angle of the spray nozzle at four planes inside the scrubber

Meanwhile, at the plane 3, the highest temperature distribution in the scrubber was observed at the right corner wall as the spray nozzle angle was $90^{\circ}$ and $100^{\circ}$ but, when the spray nozzle angle is $110^{\circ}$ and $120^{\circ}$, the temperature distribution at the left corner wall slightly decreased to the center area. This is because the seawater droplets were distributed more uniformly and freely when the spray angle becomes wider. At the plane 4, the temperature distribution slightly become uniform with decreasing of the temperature as the size opening of the spray nozzle angle become wider; the range of temperature distribution is between 300-400 $\mathrm{K}$. From this simulation, it shows as at the same plane, the similar pattern of the temperature distribution pattern was observed even though different angle of the spray nozzle was applied due to the high temperature was fed up to the scrubber and distribution process has short time constraint.

\subsection{Effect of Different Angle of the Spray Nozzle on Gas Pressure}

Figure 5 shows the simulation results of the gas pressure distribution at the different angle of the spray nozzle; 80-120 at the two planes only; plane 1 and 2 inside the scrubber. The red color in the pressure contour represents the highest pressure distribution with the value of $70 \mathrm{KPa}$ while the light blue color represents the lowest pressure distribution with the value of 15 $\mathrm{KPa}$.

At plane 1, the pressure distribution at the wall which is located at the opposite side of the inlet gas was higher as compared to the pressure distribution at the others plane due to the sudden impact occurred as the hot air was injected to the scrubber through the inlet gas. The pressure range achieved at the scrubber left corner wall at the plane 1 is about $28 \mathrm{kPa}$ while at the right corner wall is about $63 \mathrm{kPa}$. The collision between the seawater droplets and hot air has a tendency to cool down the hot air as well as its ability to reduce the pressure at the plane 2, 3 and 4 until it reaches the atmospheric pressure at the outlet gas of the scrubber. At plane 3 and 4 , the pressure drop occurred are too small causing the contour color looks not much vary between each other.

In case of a different angle of the spray nozzle on the flow pattern of gas pressure distribution, it was observed that only a small difference of pressure drop occurred at plane 2 to plane 4 . When the size of the spray nozzle angle of $80^{\circ}$ until $120^{\circ}$ is applied, merely $0.34 \%$ of pressure drop occurred at the plane 2, while for the plane 3 and plane 4, the pressure drop occurred only at $0.31 \%$ and $1.37 \%$, respectively. Thus, to emphasize the effect of different angle of the spray nozzle on the gas pressure distribution, the comparison was done only with plane 1 and 2 . Since the pressure contour color does not show much difference between each other plane, the graph of pressure against the spray nozzle angle at plane 2 has been plotted as shown in Figure 6. From the graph, it shows that the pressure drop indeed occurred which was around $0.10 \mathrm{kPa}$ when the spray nozzle angle used was increased.

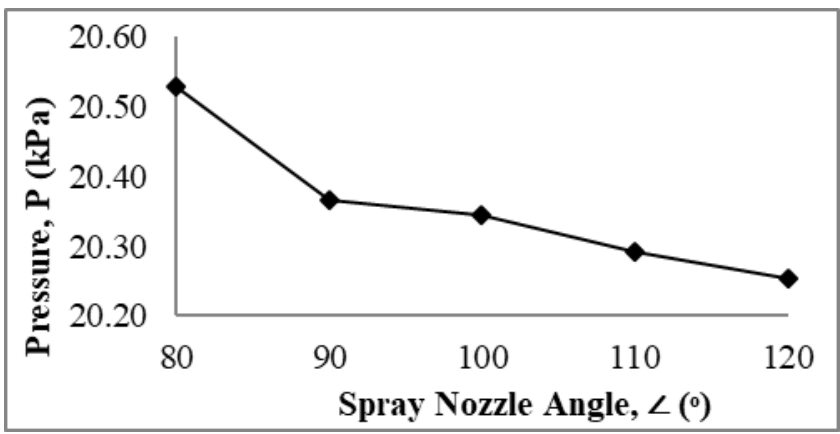

Figure $6 \mathrm{~A}$ pressure at a different angle of the spray nozzle at plane 2 


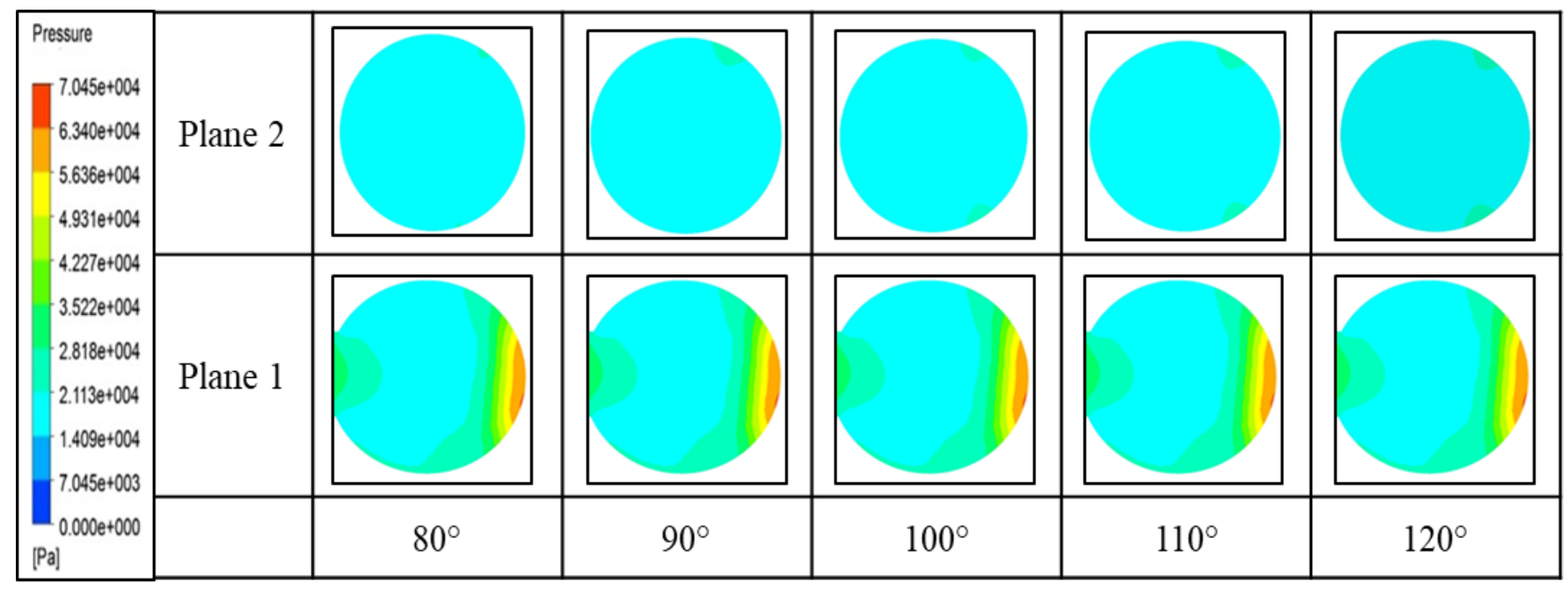

Figure 5 Gas pressure distribution at a different angle of the spray nozzle inside the scrubber

\subsection{Optimization Condition for Reduction of $\mathrm{SO}_{2}$ in a Scrubber}

From the above simulation results, it shows that at the plane 4, the highest value of the gas velocity distribution and gas temperature were achieved when the spray nozzle angle of $110^{\circ}$ was applied, based on these optimum condition, the release gas of $\mathrm{SO}_{2}$ from the scrubber was determined. The reduction of $\mathrm{SO}_{2}$ occurred in the scrubber was determined based on the calculation from the differential of mass fraction of $\mathrm{SO}_{2}$ that feed at the inlet and the released gas at the outlet gas. With the mass fraction of $\mathrm{SO}_{2}$ feed at the inlet gas is set up as $0.25 \mathrm{w} / \mathrm{w} \%$, the mass fraction of $\mathrm{SO}_{2}$ at the outlet gas is determined.

The percentage reduction of $\mathrm{SO}_{2}$ achieved in the scrubber is shown as in Figure 7 that was calculated by differential before and after entering the scrubber. It shows the percentage of $\mathrm{SO}_{2}$ reduction is increased as the size of the spray nozzle angle become wider up to $110^{\circ}$ spray nozzle angle and sudden decreased after that. Thus, it was concluded through this study, the highest percentage reduction of $\mathrm{SO}_{2}$ was achieved at $110^{\circ}$ spray nozzle angle based on the optimum condition.

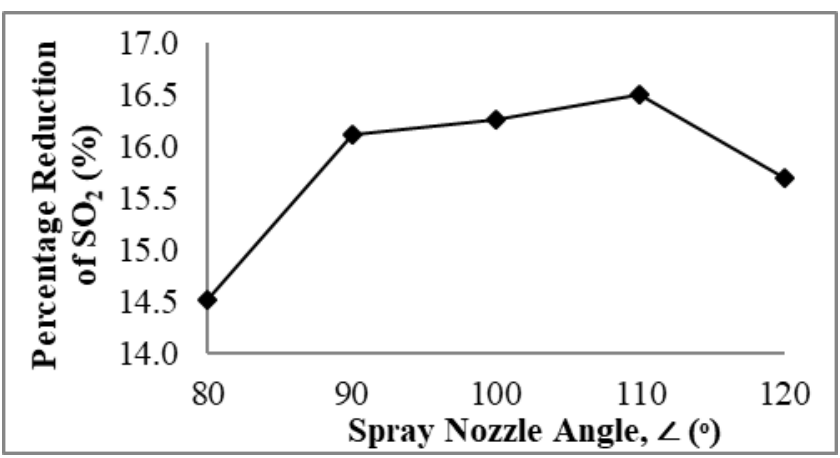

Figure 7 Percentage reduction of $\mathrm{SO}_{2}$ occurs in a scrubber at different spray nozzle angle

\subsection{Comparison with Others Simulation Result}

From the experimental studies and simulation works by Caiazzo et al. [2-4], they found that the desulfurization performance improved by increasing the liquid flow rate and gas residence time, and by decreasing the $\mathrm{SO}_{2}$ concentration. $\mathrm{SO}_{2}$ capture efficiencies up to $93 \%$ were measured under the present operating conditions. Though, in this simulation studies, the removal of $\mathrm{SO}_{2}$ gas reduction achieved less than $17 \%$ only. It due to the limitation of computation study and constraint of the scrubber design and boundary conditions.

\subsection{CONCLUSION}

The angle of the spray nozzle shows some effects on the gas distribution inside the scrubber. Overall, it shows the gas velocity, pressure and temperature distribution inside the seawater scrubber are decreased as the opening size of the spray nozzle angle used was increased. Besides, the percentage reduction of $\mathrm{SO}_{2}$ is increased as the spray nozzle angle applied become wider up to $110^{\circ}$. It was concluded that the optimum spray nozzle angle is $110^{\circ}$ since it gives the maximum percentage reduction of $\mathrm{SO}_{2}$ which was $16.49 \%$ and at the same time it can reduce the gas velocity around $7.3 \%$ which is much lower than spray angle of $100^{\circ}$ at the wall which makes the water droplets can be distributed more uniformly to the entire scrubber area. With these simulation results, the engineers are able to assess the quality of the sprayers in the actual spraying area, thus reducing the rate of $\mathrm{SO}_{2}$ emissions to the environment 


\section{Acknowledgement}

This research is fully supported by GUP grant, GUP2017-063. The authors fully acknowledged Universiti Kebangsaan Malaysia for the approved fund which makes this important research viable and effective.

\section{References}

[1] Anders, A., Stefan, M. 2007. Use of Seawater Scrubbing for $\mathrm{SO}_{2}$ Removal from Marine Engine Exhaust Gas. Energy \& Fuels. 21: 3274-3279.

DOI: https://doi.org/10.1021/ef700359w.

[2] Caiazzo, G.; Di, N.A., Langella, G. and Scala, F. 2012. Seawater Scrubbing Desulphurization: A Model for $\mathrm{SO}_{2}$ Absorption in Fall-down Droplets. Environmental Progress \& Sustainable Energy. 31: 277-287.

DOI: https://doi.org/10.1002/ep.10541.

[3] Caiazzo, G., Di, N. A., Langella, G., and Scala, F. 2009. Numerical Evaluation of Sea Water Scrubber's Efficiency for Exhaust Gas Desulphurization. Italian Section of the Combustion Institute, 32nd Meeting on Combustion 2009 Rome, Italy, 26-28 April.

[4] Caiazzo, G., Miccio, F., and Scala, F. 2013. Modelling Heat and Mass Transfer in a Seawater Scrubber for Marine Application: Some Improvements Based on a CFD Simulation. XXXVI Meeting of the Italian Section of the Combustion Institute, Italy, 2013.

[5] Chris, W. 2015. Behemoths of Emission: How a Container Ship Can Out-pollute 50 Million Cars. Available online: http://www.enfos.com/blog/behemoths-of-emission-how-acontainer-ship-can-out-pollute-50-million-cars/ 2015, (24 November 2017)

[6] Claudio, A., and Carletti, G. 2015. New Aspects in Limestone Dissolution for Wet Flue Gas Desulphurization. PhD Thesis. Abo Academy University, Finland.

[7] Giuseppe, C., Gluseppe, L., Francesco, M., and Fabrizio, S. 2012. An Experiment Investigation on Seawater $\mathrm{SO}_{2}$ Scrubbing for Marine Application. Environmental Progress \& Sustainable Energy. 32: 4. DOI: https://doi.org/10.1002/ep.11723.

[8] Jabatan Laut Malaysia. 2011. Implementation of the International Convention for the Prevention of Pollution from Ships 1973 as Amended (MARPOL ANNEX VI Regulations for the Prevention of Air Pollution from Ships). Jabatan Lau Malaysia 2011.

[9] Larson A. 2018. Supreme Court Strikes Down EPA's MATS Rule. Power. 2018: 2.

DOI: http://www.powermag.com/supreme-court-strikesdown-epas-mats-rule/?printmode $=0$.
[10] University of Vaasa. 2018. New Scrubber Does Not Pollute Sea Water. ScienceDaily. 2018 http://www.sciencedaily.com/releases/2016/02/1602230747 43.html.

[11] Everson, R. C., Arif, A., and Neomagus, H. W. J. P. 2014. CFD Modelling and Simulations of an Industrial Wet Flue Gas Desulphurization Unit. $6^{\text {th }}$ International Freiberg Conference on IGCC \& XtL Technologies, Coal Conversion and Syngas. Dresden/Radabeul, Germany, 2014, 19-22 May.

[12] Lamas, M. I., Rodriguez, C. G., Rodriguez, J. D., and Telmo, J. 2016. Numerical Model of $\mathrm{SO}_{2}$ Scrubbing with Seawater Applied to Marine Engine. Polish Maritime Research. 2(90): 42-47. DOI: https://doi.org/10.1515/pomr-2016-0019.

[13] Brown, F. Li, K. J., Kalata, W., and Schick, R. J. 2013. Analysis and Optimization of spray Tower in WFGD. ILASS Americas, $25^{\text {th }}$ Annual Conference on Liquid Atomization and Spray Systems, Pittsburgh, PA, May, 2013.

[14] Ansys, Inc. 2013. Ansys fluent in Ansys Workbench User's Guide. Ansys, Inc.

[15] A User's Guide to Spray Nozzles, TeeJet Technology, Spray System Co.

[16] Wärtsilä, Scrubber Product Guide, November 2014.

[17] Kumaresh, S., and Man; Y. K. 2015. Numerical investigation of the flow Characteristics inside the scrubber unit. World Academy of Science, Engineering and Technology. International Journal of Mechanical Aerospace, Industrial, Mechatronic and Manufacturing Engineering. 9(2): 224-228. DOI: $\quad$ https://waset.org/publications/10000341/numericalinvestigation-of-the-flow-characteristics-inside-the-scrubberunit.

[18] Giuseppe, C., Gluseppe, L., Francesco, M., and Fabrizio, S. 2011. Seawater Scrubbing Desulfurization: A Model for $\mathrm{SO}_{2}$ Absorption in Fall-down Droplets. Environmental Progress \& Sustainable Energy AICHE. 31 (2): 277-287. DOI: https://doi.org/10.1002/ep.10541.

[19] Andreasen, A., and Mayer, S. 2007. Use of Seawater Scrubbing for $\mathrm{SO}_{2}$ Removal from Marine Engine Exhaust Gas. Energy \& Fuels. 21: 3274-3279.

[20] Chen, W. H. 2001. Unsteady Absorption of Sulfur Dioxide by an Atmospheric Water Droplet with Internal Circulation, Atmospheric Environment. 35: 2375-2393. DOI: https://doi.org/10.1016/S1352-2310(00)00536-7.

[21] Elperin, T., and Fominykh, A. 2005. Conjugate Mass Transfer during Gas Absorption by Falling Liquid Droplet with Internal Circulation. Atmospheric Environment. 39: 4575-4582. DOI: https://doi.org/10.1016/j.atmosenv.2005.04.005.

[22] Argyropoulos, C. D., and Markatos, N. C. 2015. Recent Advances on the Numerical Modelling of Turbulent Flows. Applied Mathematical Modelling. 39(2): 693-732. DOI: https://doi.org/10.1016/j.apm.2014.07.001. 